\title{
Efikasi dan Berbagai Konsentrasi Tiga Jenis Herbisida terhadap Gulma pada Pertanaman Jagung Manis (Zea mays saccharata Sturt)
}

\author{
Efficacy and Various Concentrations of Three Types of Herbicides on \\ Weeds at Sweet Corn Plantations (Zea mays saccharata Sturt) \\ Aristiawan Herdiansyah ${ }^{1}$, Jenal Mutakin ${ }^{2}$, Atak Tauhid ${ }^{2}$ \\ ${ }^{1}$ Program Studi Agroteknologi, Fakultas Pertanian, Universitas Garut \\ Jalan Raya Samarang 52A, Tarogong Kaler, Garut, Jawa Barat \\ e-mail:jenalmutakin@uniga.ac.id
}

\begin{abstract}
ABSTRAK
Penelitian ini bertujuan untuk mempelajari efikasi dan berbagai konsentrasi tiga jenis herbisida terhadap gulma pada pertanaman jagung manis (Zea mays saccharata Sturt). Percobaan dilaksanakan di Desa Kersamanah Kecamatan Kersamanah Kabupaten Garut dengan ketinggian tempat 553 m di atas permukaan laut, jenis tanah Inceptisol. Tipe curah hujan berdasarkan kriteria Schmidt dan Ferguson (1951) adalah tipe curah hujan C dengan rata- rata temperatur. Percobaan dilaksanakan pada bulan Agustus sampai Oktober 2018. Metode yang digunakan adalah metode eksperimen eksperimental dengan menggunakan Rancangan Acak Kelompok (RAK) pola faktorial 3 x 3 yang diulang dua kali. Herbisida $(\mathrm{H})$ dengan empat taraf, yaitu: Kontrol $\left(\mathrm{h}_{0}\right)$, Calaris $\left(\mathrm{h}_{1}\right)$, Roundup $\left(h_{2}\right)$, Adengo $\left(h_{3}\right)$. Konsentrasi $(K)$ berperan sebagai faktor kedua dengan empat taraf, yaitu: Kontrol $\left(\mathrm{k}_{0}\right), 1,5 \mathrm{ml} /$ liter air $\left(\mathrm{k}_{1}\right), 3 \mathrm{ml} /$ liter air $\left(\mathrm{k}_{2}\right), 4,5 \mathrm{ml}$ / liter air $\left(\mathrm{k}_{3}\right)$. Hasil penelitian menunjukkan tidak terjadi interaksi pada setiap variabel pengamatan. Taraf perlakuan herbisida Calaris dengan konsentrasi 3 $\mathrm{ml} /$ liter air menunjukkan pengaruh paling baik terhadap tinggi tanaman, perkecambahan, pembungaan, pengendalian gulma dan aspek kualitas.
\end{abstract}

Kata Kunci : Efikasi, Herbisida dan Tanaman Jagung Manis

\section{ABSTRACT}

This study aims to study the efficacy and various concentrations of three types of herbicides against weeds in sweet corn plantations (Zea mays saccharata Sturt). The experiment was carried out in Kersamanah Village, Kersamanah Subdistrict, Garut Regency with a height of $553 \mathrm{~m}$ above sea level, the type of soil Inceptisol. The type of rainfall based on Schmidt and Ferguson criteria 
(1951) is the type of rainfall $\mathrm{C}$ with an average temperature. The trial will take place from August to October 2018. The method used was experimental experimental method using a Randomized Block Design (RBD) factorial pattern of 3 x 3 which was repeated twice. Herbicide $(\mathrm{H})$ with four levels, namely: Control (h0), Calaris (h1), Roundup (h2), Adengo (h3). The concentration (K) acts as the second factor with four levels, namely: Control (k0), $1.5 \mathrm{ml} /$ liter of water (k1), $3 \mathrm{ml} /$ liter of water (k2), $4.5 \mathrm{ml} /$ liter of water (k3). The results of the study showed that there was not the interaction on each observation variable. The level of Calaris herbicide treatment with a concentration of $3 \mathrm{ml} /$ liter of water showed the best influence on plant height, germination, flowering, weed control and quality aspects.

Keywords: Efficacy, Herbicides and Sweet Corn Plants

\section{PENDAHULUAN}

Jagung manis atau sweet corn (Zea mays saccharata Sturt) termasuk dalam tanaman pangan, merupakan tipe jagung yang baru dikembangkan masyarakat Indonesia. Jagung manis semakin populer dan banyak dikonsumsi karena memiliki rasa yang manis dibandingkan jagung biasa. Selain rasanya, keunggulan jagung manis adalah mempunyai nilai ekonomis yang tinggi di pasaran, masa produksi yang relatif lebih cepat, banyak mengandung Kandungan gizi Jagung manis Energi 96 Kal, Protein 3,5 g, Lemak 1,0 g, Karbohidrat 22,8 g, Kalsium 3,0 mg, Fosfor 11,0 mg, Besi 0,7 mg, Vitamin A $400 \mathrm{Si}$, Vitamin B 0,15 mg, Vitamin C 12 mg, Air 72,2 g (USDA Agr. Hand Book No. 8 Composition of Food Raw, Processed Prepared Revised, 1963).

Produksi tanaman jagung pada tahun 2014 cenderung mengalami peningkatan. Produksi tanaman jagung tahun 2016 mencapai 23,58 juta ton atau meningkat 20,22\% dari tahun 2015 sebesar 19,61 juta ton, dan produksi tahun 2017 meningkat 10,39\% menjadi 26,03 juta ton (BPS, 2018). Salah satu aspek budidaya tanaman Jagung manis yang sangat penting adalah pengendalian terhadap gulma. Gulma dapat menurunkan hasil dengan cara berkompetisi dengan tanaman pokok, disamping itu gulma dapat sebagai inang alternatif hama dan penyakit tanaman. Apabila gulma yang ada sebagai inang pengganti hama penyakit, maka penurunan hasilnya sangat merugikan perkebunan, oleh sebab itu perlu adanya tindakan pengendalian untuk menekan perkembangan gulma di 
areal pertanaman. Menurut Isna (2016), ada beberapa metode pengendalian gulma yaitu pengendalian dengan mekanis, pengendalian budidaya/kultur teknis, hayati, pengendalian terpadu, dan kimiawi.

Pengendalian gulma secara kimia (herbisida) merupakan salah satu cara yang dianggap dapat dijadikan sebagai cara yang efektif dan efisien. Efektivitasherbisida dalam penggunaan tenaga kerja dan biaya yang cenderung lebih ekonomis menyebabkan penggunaan herbisida dalam mengendalikan gulma diareal pertanaman jagung manis sangat dominan. Selain itu, keuntungan herbisida lainnya adalah mampu menekan pertumbuhan gulma tanpa mengganggu tanaman pokok (Sukman dan Yakup, 1995).

\section{METODE PENELITIAN}

Penelitian dilaksanakan di Desa Kersamanah Kecamatan Kersamanah Kabupaten Garut dengan ketinggian tempat $553 \mathrm{~m}$ di atas permukaan laut, jenis tanah Inceptisol yaitu pH: $\mathrm{H}_{2} 0$ 7,2, pH: $\mathrm{KCl}$ IN $(5,4)$. Tanah ini mengandung COrganik $(5,85)$ rendah, $\mathrm{C} / \mathrm{N}$ rendah $(4,5) \mathrm{K}$ potensial rendah, $\mathrm{P}$ potensial tinggi, KTK rendah $(13,23)$, dan kejenuhan basa sangat tinggi $(115,74)$. Tanah ini memiliki tekstur Liat (9\%), Pasir (71\%), dan debu (20\%). Percobaan dilaksanakan pada bulan Agustus sampai Oktober 2018. Tipe curah hujan berdasarkan kriteria Schmidt dan Ferguson (1951) adalah tipe curah hujan C dengan rata-rata temperatur harian $28^{0} \mathrm{C}$. Bahan yang digunakan dalam percobaan: benih jagung manis kultivar Bonanza F1, air, pupuk organik, pupuk tambahan kimia N, P, K sebagai pupuk dasar, herbisida Calaris, Roundup, dan Adengo sesuai dengan perlakuan yang di uji. Alat yang akan digunakan antara lain; ember, cangkul, kored, papan nama, alat tulis, roll meter, bingkai atau frame, hand sprayer, karung, timbangan digital.

Metode yang digunakan dalam penelitian ini adalah metode eksperimental dengan menggunakan Rancangan Acak Kelompok (RAK) pola faktorial 4 x 4 yang diulang 2 kali. Faktor pertama adalah jenis herbisida, diberi simbol $(\mathrm{H})$ dengan 3 taraf, yaitu : h0 = Kontrol / tanpa perlakuan, h1 = Calaris $550 \mathrm{SC}$, h2 = Roundup 486 SL, h3 = Adengo 315 SC. Faktor kedua adalah konsentrasi herbisida dengan simbol $(\mathrm{K})$ dengan 3 taraf, yaitu : $\mathrm{k} 0=$ kontrol / tanpa perlakuan, 
$\mathrm{k} 1=1,5 \mathrm{ml} /$ liter air , $\mathrm{k} 2=3 \mathrm{ml} /$ liter air, $\mathrm{k} 3=4,5 \mathrm{ml} /$ liter air. Kombinasi perlakuan ke dua faktor tersebut diketahui 16 kombinasi taraf perlakuan sehingga dari 2 ulangan diperoleh 32 plot kombinasi perlakuan, dalam 1 plot terdapat 16 tanaman jagung manis. Penelitian diuji dengan analisis ragam, jika terdapat perbedaan yang nyata akan diuji lanjut menggunakan uji jarak berganda Duncan.

\section{HASIL DAN PEMBAHASAN}

\section{Perkecambahan}

Hasil analisis statistik menunjukkan tidak terjadi interaksi antara perlakuan efikasi dan berbagai konsentrasi tiga jenis herbisida terhadap gulma pada tanaman jagung manis terhadap perkecambahan. Data pengamatan dapat dilihat pada Lampiran 7. Lebih jelasnya hasil analisis data rata-rata perkecambahan dapat dilihat pada Tabel 3.

Tabel 3. Perkecambahan.

\begin{tabular}{lc}
\hline Perlakuan & Rata-rata Perkecambahan \\
\hline Herbisida & \\
$\mathrm{h}_{0}=$ Kontrol / tanpa perlakuan & $67,5 \mathrm{a}$ \\
$\mathrm{h}_{1}=$ Calaris & $72,92 \mathrm{a}$ \\
$\mathrm{h}_{2}=$ Roundup & $71,67 \mathrm{a}$ \\
$\mathrm{h}_{3}=$ Adengo & $71,25 \mathrm{~b}$ \\
konsentrasi & \\
$\mathrm{k}_{0}=$ kontrol / tanpa perlakuan & $68,75 \mathrm{a}$ \\
$\mathrm{k}_{1}=1,5 \mathrm{ml} /$ liter air & $72,08 \mathrm{a}$ \\
$\mathrm{k}_{2}=3 \mathrm{ml} /$ liter air & $72,50 \mathrm{a}$ \\
$\mathrm{k}_{3}=4,5 \mathrm{ml} /$ liter air & $70,00 \mathrm{a}$ \\
\hline
\end{tabular}

Keterangan : Angka rata-rata yang diikuti huruf yang sama pada kolom tidak berbeda nyata menurut Uji Jarak Berganda Duncan pada taraf nyata $5 \%$.

Faktor perlakuan $\mathrm{H}$ menunjukkan taraf faktor $\mathrm{h}_{1}$ tidak berbeda nyata dengan taraf faktor $h_{2}$ dan $h_{3}$, tetapi berbeda nyata dengan $h_{0}$. Taraf faktor $h_{3}$ menunjukkan perkecambahan tetinggi dibandingkan dengan yang lainnya. Faktor perlakuan $\mathrm{K}$ menunjukkan taraf faktor $\mathrm{k}_{1}$ tidak berbeda nyata dengan taraf faktor $\mathrm{k}_{2}$ dan $\mathrm{k}_{3}$, tetapi berbeda nyata dengan $\mathrm{k}_{0}$. Hal ini menunjukkan bahwa penggunaan herbisida adengo lebih efektif mengendalikan gulma pada lahan jagung, dikarenakan persaingan gulma dengan tanaman jagung memperebutkan 
air, unsur hara dan sinar matahari menyebabkan terganggunya proses pertumbuhan gulma. Pertumbuhan dan hasil suatu tanaman dipengaruhi oleh faktor partumbuhan tanaman misalnya air, unsur hara dan cahaya (Hassanudin $d k k ., 2012)$.

\section{Gejala Keracunan Jagung}

Hasil analisis statistik menunjukkan tidak terjadi interaksi antara perlakuan efikasi dan berbagai konsentrasi tiga jenis herbisida terhadap gulma pada tanaman jagung manis terhadap gejala keracunan jagung. Data pengamatan dapat dilihat pada Lampiran 8, 9, 10 dan 11. Lebih jelasnya hasil analisis data rata-rata gejala keracunan jagung dapat dilihat pada Tabel 4.

Tabel 4. Gejala Keracunan Jagung

\begin{tabular}{lllll}
\hline \multirow{2}{*}{ Perlakuan } & \multicolumn{4}{c}{ Rata-rata Gejala Keracunan Jagung (\%) } \\
\cline { 2 - 5 } Herbisida & $3 \mathrm{HSA}$ & $5 \mathrm{HAS}$ & 7 HSA & $10 \mathrm{HAS}$ \\
$\mathrm{h}_{0}=$ Kontrol / tanpa perlakuan & $0,71 \mathrm{a}$ & $0,71 \mathrm{a}$ & $0,71 \mathrm{a}$ & $0,71 \mathrm{a}$ \\
$\mathrm{h}_{1}=$ Calaris & $3,68 \mathrm{~b}$ & $3,40 \mathrm{~b}$ & $3,26 \mathrm{~b}$ & $2,79 \mathrm{~b}$ \\
$\mathrm{~h}_{2}=$ Roundup & $3,06 \mathrm{~b}$ & $3,43 \mathrm{~b}$ & $3,57 \mathrm{~b}$ & $3,49 \mathrm{~b}$ \\
$\mathrm{~h}_{3}=$ Adengo & $3,57 \mathrm{~b}$ & $4,07 \mathrm{c}$ & $4,05 \mathrm{~b}$ & $3,68 \mathrm{~b}$ \\
Konsentrasi & & & & \\
$\mathrm{k}_{0}=$ kontrol / tanpa perlakuan & $0,71 \mathrm{a}$ & $0,71 \mathrm{a}$ & $0,71 \mathrm{a}$ & $0,71 \mathrm{a}$ \\
$\mathrm{k}_{1}=1,5 \mathrm{ml} /$ liter air & $3,42 \mathrm{~b}$ & $3,37 \mathrm{~b}$ & $3,18 \mathrm{~b}$ & $2,93 \mathrm{~b}$ \\
$\mathrm{k}_{2}=3 \mathrm{ml} /$ liter air & $3,26 \mathrm{~b}$ & $3,30 \mathrm{~b}$ & $3,59 \mathrm{~b}$ & $3,35 \mathrm{~b}$ \\
$\mathrm{k}_{3}=4,5 \mathrm{ml} /$ liter air & $3,63 \mathrm{~b}$ & $3,86 \mathrm{~b}$ & $4,11 \mathrm{~b}$ & $3,68 \mathrm{~b}$ \\
\hline
\end{tabular}

Keterangan : Angka rata-rata yang diikuti huruf yang sama pada kolom tidak berbeda nyata menurut Uji Jarak Berganda Duncan pada taraf nyata $5 \%$.

Berdasarkan hasil pengamatan secara visual pada setiap waktu pengamatan menunjukkan bahwa tidak terdapat gejala keracunan pada tanaman jagung (Zea mays L.). Hal ini sejalan dengan hasil pengamatan tinggi tanaman dan persen perkecambahan menunjukkan bahwa herbisida tidak mempengaruhi tanaman jagung. Seperti hasil penelitian Khan (2014) yang menunjukkan bahwa tidak terdapat gejala keracunan pada lahan tanaman jagung yang diaplikasi 
herbisida baik tunggal maupun campuran.

Pengendalian gulma secara kimiawi dengan menggunakan herbisida memiliki efek yang lebih cepat dalam pelaksanaan pengendaliannya, dibandingkan jika dilakukan secara manual. Salah satu pertimbangan yang penting dalam pemakaian herbisida adalah untuk mendapatkan pengendalian yang selektif, yaitu mematikan gulma tetapi tidak merusak tanaman budidaya.

\section{Persentase Pengendalian Gulma}

Hasil analisis statistik menunjukkan tidak terjadi interaksi antara perlakuan efikasi dan berbagai konsentrasi tiga jenis herbisida terhadap gulma pada tanaman jagung manis terhadap pengendalian gulma. Data pengamatan dapat dilihat pada Lampiran 12. Lebih jelasnya hasil analisis data rata-rata penutupan gulma terlihat pada Tabel 5.

Tabel 5. Pengendalian Gulma.

\begin{tabular}{lc}
\hline \multicolumn{1}{c}{ Perlakuan } & Rata-rata Pengendalian Gulma (\%) \\
\hline Herbisida & \\
$\mathrm{h}_{0}=$ Kontrol / tanpa perlakuan & $13,46 \mathrm{a}$ \\
$\mathrm{h}_{1}=$ Calaris & $23,92 \mathrm{~b}$ \\
$\mathrm{~h}_{2}=$ Roundup & $23,46 \mathrm{~b}$ \\
$\mathrm{~h}_{3}=$ Adengo & $23,83 \mathrm{~b}$ \\
\hline Konsentrasi & \\
$\mathrm{k}_{0}=$ kontrol / tanpa perlakuan & $12,42 \mathrm{a}$ \\
$\mathrm{k}_{1}=1,5 \mathrm{ml} /$ liter air & $24,17 \mathrm{~b}$ \\
$\mathrm{k}_{2}=3 \mathrm{ml} /$ liter air & $25,29 \mathrm{~b}$ \\
$\mathrm{k}_{3}=4,5 \mathrm{ml} /$ liter air & $22,79 \mathrm{~b}$ \\
\hline
\end{tabular}

Keterangan : Angka rata-rata yang diikuti huruf yang sama pada kolom tidak berbeda nyata menurut Uji Jarak Berganda Duncan pada taraf nyata $5 \%$.

Taraf faktor $\mathrm{H}$ menunjukkan semua taraf faktor $\mathrm{h}_{1}$ tidak berbeda nyata dengan taraf faktor $h_{2}$ dan $h_{3}$, tetapi berbeda nyata dengan $h_{0}$. Taraf faktor $h_{1}$ menunjukkan tingkat pengendalian gulma dibandingkan dengan yang lainnya. Faktor perlakuan $\mathrm{K}$ menunjukkan taraf faktor $\mathrm{k}_{1}$ tidak berbeda nyata dengan taraf faktor $\mathrm{k}_{2}$ dan $\mathrm{k}_{3}$, tetapi berbeda nyata dengan $\mathrm{k}_{0}$. Hal ini dapat dikatakan bahwa dengan konsentrasi yang tepat, herbisida telah menekan pertumbuhan gulma, dalam hal ini adalah peningkatan persentase pengendalian gulma. Terlihat juga 
bahwa jenis herbisida pendimethalin dapat meningkatkan persentase pengendalian gulma. Hasil penelitian itu sejalan dengan yang dilakukan oleh Cullpepper \& York (2000), Tharp \& Kells (2000) bahwa gulma rumputrumputan dan berdaun lebar setahun dan tahunan dapat dikendalikan dengan herbisida pendimethalin.

Tingginya persentase pengendalian gulma ditentukan oleh dosis herbisida, juga ditentukan oleh faktor iklim seperti kelembapan relatif. Berdasarkan hasil penelitian yang dilaksanakan oleh Wichert \& Talbert (1992) bahwa, terdapat peningkatan pengendalian jenis gulma manakala kelembapan relatif meningkat dari $50 \%$ menjadi $85 \%$. Berdasarkan pengamatan di lapangan, gulma sasaran yang terkena herbisida, menunjukkan pertumbuhan tidak normal. Abnormalitas gulma tersebut pada akhirnya akan menimbulkan kematian. Ditegaskan Reade \& Cobb (2002) bahwa pertumbuhan yang tidak normal merupakan aktualisasi proses penghambatan dalam pemasangan mikrotubula.

\section{Tinggi Tanaman}

Hasil analisis statistik menunjukkan tidak terjadi interaksi antara perlakuan efikasi dan berbagai konsentrasi tiga jenis herbisida terhadap gulma pada tanaman jagung manis terhadap tinggi tanaman. Data pengamatan dapat dilihat pada Lampiran 13 dan 14. Lebih jelasnya hasil analisis data rata-rata tinggi tanaman dapat dilihat pada Tabel 6.

Taraf perlakuan $\mathrm{H}$ pada semua umur menunjukkan taraf faktor $\mathrm{h}_{1}$ tidak berbeda nyata dengan taraf faktor $h_{2}$ dan $h_{3}$ tetapi berbeda nyata dengan $h_{0}$. Dilihat dari pengamatan taraf faktor $\mathrm{h}_{1}$ menunjukkan rata-rata tinggi tanaman yang lebih tinggi.

Hal ini sesuai berdasarkan rekomendasi yang dikeluarkan oleh Direktorat Jenderal Tanaman Pangan (2010) dan hasil Penelitian Hasanuddin dkk. (2012) bahwa gulma rumput-rumputan dan berdaun lebar dapat dikendalikan dengan dosis herbisida campuran. Tingginya persentase pengendalian gulma selain ditentukan oleh dosis herbisida, juga ditentukan oleh faktor iklim seperti kelembapan relatif. Berdasarkan hasil penelitian yang dilaksanakan oleh Wichert \& Talbert (1992) bahwa, terdapat peningkatan pengendalian jenis gulma 
manakala kelembapan relatif meningkat. Hasil penelitian itu sejalan dengan keadaan di lapangan

Tabel 6. Efikasi dan Berbagai Konsentrasi Tiga Jenis Herbisida terhadap Gulma Pada Tanaman Jagung Manis terhadap Tinggi Tanaman.

\begin{tabular}{lcc}
\hline \multicolumn{1}{c}{ Perlakuan } & \multicolumn{2}{c}{ Rata-rata tinggi tanaman $(\mathrm{cm})$} \\
\cline { 2 - 3 } & $25 \mathrm{HST}$ & $35 \mathrm{HST}$ \\
\hline Herbisida & & \\
$\mathrm{h}_{0}=$ Kontrol / tanpa perlakuan & $85,54 \mathrm{a}$ & $116,58 \mathrm{a}$ \\
$\mathrm{h}_{1}=$ Calaris & $100,75 \mathrm{~b}$ & $135,28 \mathrm{~b}$ \\
$\mathrm{~h}_{2}=$ Roundup & $99,53 \mathrm{~b}$ & $129,65 \mathrm{~b}$ \\
$\mathrm{~h}_{3}=$ Adengo & $95,50 \mathrm{~b}$ & $135,05 \mathrm{~b}$ \\
konsentrasi & & \\
$\mathrm{k}_{0}=$ kontrol / tanpa perlakuan & $83,65 \mathrm{a}$ & $116,53 \mathrm{a}$ \\
$\mathrm{k}_{1}=1,5 \mathrm{ml} /$ liter air & $97,68 \mathrm{~b}$ & $134,68 \mathrm{~b}$ \\
$\mathrm{k}_{2}=3 \mathrm{ml} /$ liter air & $100,88 \mathrm{~b}$ & $135,30 \mathrm{~b}$ \\
$\mathrm{k}_{3}=4,5 \mathrm{ml} /$ liter air & $9,11 \mathrm{~b}$ & $130,05 \mathrm{~b}$ \\
\hline
\end{tabular}

Keterangan : Angka rata-rata yang diikuti huruf yang sama pada setiap kolom tidak berbeda nyata menurut Uji Jarak Berganda Duncan pada taraf nyata $5 \%$.

Berdasarkan pengamatan di lapangan, gulma sasaran yang terkena herbisida, menunjukkan pertumbuhan gulma tidak normal. Abnormalitas gulma tersebut pada akhirnya akan menimbulkan kematian sehingga tingkat persaingan penyerapan unsur hara bagi tanaman menurun dan tinggi tanaman meningkat. Taraf faktor $\mathrm{K}$ pada semua umur menunjukkan taraf faktor $\mathrm{k}_{2}$ memberikan ratarata tinggi tanaman tertinggi. Hal ini disebabkan karena konsentrasi tersebut dapat mengendalikan gulma dengan baik dan tidak berdampak terhadap tanaman jagung dibandingkan dengan taraf faktor $\mathrm{k}_{3}$ yang terdapat tingkat eracunan bagi tanaman

\section{Pembungaan}

Hasil analisis statistik menunjukkan tidak terjadi interaksi antara perlakuan efikasi dan berbagai konsentrasi tiga jenis herbisida terhadap gulma pada tanaman jagung manis terhadap pembungaan. Data pengamatan dapat dilihat pada Lampiran 15. Lebih jelasnya hasil analisis data rata-rata pembungaan dapat dilihat pada Tabel 7. 
Tabel 7. Pembungaan.

\begin{tabular}{lc}
\hline \multicolumn{1}{c}{ Perlakuan } & Rata-rata Pembungaan \\
\hline Herbisida & \\
$\mathrm{h}_{0}=$ Kontrol / tanpa perlakuan & $3,78 \mathrm{a}$ \\
$\mathrm{h}_{1}=$ Calaris & $6,08 \mathrm{~b}$ \\
$\mathrm{~h}_{2}=$ Roundup & $5,54 \mathrm{a}$ \\
$\mathrm{h}_{3}=$ Adengo & $5,15 \mathrm{a}$ \\
Konsentrasi & \\
$\mathrm{k}_{0}=$ kontrol / tanpa perlakuan & $4,78 \mathrm{a}$ \\
$\mathrm{k}_{1}=1,5 \mathrm{ml} /$ liter air & $5,95 \mathrm{a}$ \\
$\mathrm{k}_{2}=3 \mathrm{ml} /$ liter air & $4,84 \mathrm{a}$ \\
$\mathrm{k}_{3}=4,5 \mathrm{ml} /$ liter air & $4,78 \mathrm{a}$ \\
\hline
\end{tabular}

Keterangan : Angka rata-rata yang diikuti huruf yang sama pada kolom tidak berbeda nyata menurut Uji Jarak Berganda Duncan pada taraf nyata $5 \%$.

Faktor Perlakuan $\mathrm{H}$ menunjukkan taraf faktor $\mathrm{h}_{0}$ tidak berbeda nyata dengan taraf faktor $h_{2}$ dan $h_{3}$ tetapi berbeda nyata dengan $h_{1}$. Faktor perlakuan $K$ menunjukkan semua taraf faktor tidak berbeda nyata. Hal ini dikarenakan perlakuan herbisida yang berbeda tidak mempengaruhi masa pembentukan bunga jantan dan bunga betina. Calaris diduga selain mengendalikan gulma juga bisa mempercepat pembentukan bunga.

\section{Aspek Kualitas}

Hasil analisis statistik menunjukkan tidak terjadi interaksi antara perlakuan efikasi dan berbagai konsentrasi tiga jenis herbisida terhadap gulma pada tanaman jagung manis terhadap aspek kualitas. Lebih jelasnya hasil analisis data rata-rata aspek kualitas terlihat pada Tabel 8.

Taraf faktor $\mathrm{H}$ menunjukkan semua taraf faktor $\mathrm{h}_{1}$ tidak berbeda nyata dengan taraf faktor $h_{2}$ dan $h_{3}$, tetapi berbeda nyata dengan $h_{1}$. Taraf faktor $h_{1}$ menunjukkan tingkat pengendalian gulma dibandingkan dengan yang lainnya. Faktor perlakuan $\mathrm{K}$ menunjukkan taraf faktor $\mathrm{k}_{1}$ tidak berbeda nyata dengan taraf faktor $\mathrm{k}_{2}$ dan $\mathrm{k}_{3}$, tetapi berbeda nyata dengan $\mathrm{k}_{2}$. Prinsip utama dalam pengendalian gulma pada budidaya tanaman ialah menekan populasi gulma sebelum merugikan tanaman. 
Tabel 8. Aspek Kualitas.

\begin{tabular}{lc}
\hline Perlakuan & Aspek kualitas Grade A (\%) \\
\hline Herbisida & \\
$\mathrm{h}_{0}=$ Kontrol / tanpa perlakuan & $0,71 \mathrm{a}$ \\
$\mathrm{h}_{1}=$ Calaris & $3,08 \mathrm{~b}$ \\
$\mathrm{~h}_{2}=$ Roundup & $2,95 \mathrm{~b}$ \\
$\mathrm{~h}_{3}=$ Adengo & $2,98 \mathrm{~b}$ \\
\hline Konsentrasi & \\
$\mathrm{k}_{0}=$ kontrol / tanpa perlakuan & $0,77 \mathrm{a}$ \\
$\mathrm{k}_{1}=1,5 \mathrm{ml} /$ liter air & $2,98 \mathrm{~b}$ \\
$\mathrm{k}_{2}=3 \mathrm{ml} /$ liter air & $3,01 \mathrm{~b}$ \\
$\mathrm{k}_{3}=4,5 \mathrm{ml} /$ liter air & $2,96 \mathrm{~b}$ \\
\hline
\end{tabular}

Keterangan : Angka rata-rata yang diikuti huruf yang sama pada kolom tidak berbeda nyata menurut Uji Jarak Berganda Duncan pada taraf nyata $5 \%$.

Penundaan pengendalian gulma sampai gulma berbunga akan memberikan kesempatan gulma untuk berkembangbiak dan penyebaran gulma pada lahan budidaya (Puspitasari $d k k$., 2013). Hendrival $d k k$ (2014), menyatakan bahwa untuk memperoleh kualitas maupun kuantitas produksi secara maksimal pengendalian gulma perlu diperhatikan dan frekuensi pengendalian gulma tergantung pada pertumbuhan gulma di lahan budidaya.

Menurut Hardiman (2013), gulma ialah tumbuhan yang tidak dikehendaki oleh manusia karena dapat mengganggu pertumbuhan tanaman pokok. Fitriana (2008) menyatakan bahwa gulma yang tumbuh bersama tanaman dapat mengurangi kualitas dan kuantitas hasil tanaman. Faktor-faktor penting yang menentukan pertumbuhan gulma adalah cahaya, suhu, air, angin, kelembaban, dan aspek musim (Zimdahl, 2007). Gulma berkompetisi sepanjang siklus hidup tanaman pokok tetapi keberadaan gulma lebih sensitif pada periode kritis.

\section{Pengamatan Penunjang}

Jenis tanah di Kecamatan Kersamanah tempat penelitian adalah Inceptisol. Selama percobaan terjadi gangguan hama yaitu hama penggerek buah dan batang (Heliothis armigera.), hama tersebut selain menyerang pada bagian tongkol, hama ini juga memakan daun dan batang jagung.

Curah hujan di Wilayah Kecamatan Kersamanah Kabupaten Garut 
dengan nilai $\mathrm{Q}=55,71 \%$ termasuk ke dalam tipe curah hujan $\mathrm{C}$, yaitu agak basah.

\section{KESIMPULAN}

Berdasarkan hasil penelitian mengenai efikasi dan berbagai konsentrasi tiga jenis herbisida terhadap gulma pada pertanaman jagung manis (Zea mays saccharata Sturt) dapat disimpulkan :

1. Tidak terjadi interaksi antara perlakuan efikasi dan berbagai konsentrasi tiga jenis herbisida terhadap gulma pada pertanaman jagung manis pada setiap pengamatan.

2. Secara mandiri perlakuan herbisida Calaris dan konsentrasi $3 \mathrm{ml} /$ liter air memberikan pengaruh terbaik terhadap tinggi tanaman, perkecambahan, pembungaan, pengendalian gulma dan aspek kualitas.

\section{DAFTAR PUSTAKA}

Bogor. Badan Pusat Statistik. 2011-2012. Tanaman Pangan www.bps.go.id/tnmn_pgn.php (Diakses pada tanggal 26 Juli 2017).

Culpepper, A.S., and A.C. York. 2000. Weed management in ultra narrow row cotton (Gossypium hirsutum). Weed Technol. 14:19-29.

Direktorat Jenderal Tanaman Pangan. 2010. Pestisida untuk pertanian dan kehutanan. Direktorat Jenderal Tanaman Pangan. Jakarta.

Fitriana, M. 2008. Pengaruh Periode Penyiangan Gulma terhadap Pertumbuhan dan Hasil Tanaman Kacang Hijau (Vigna radiate L.) Varietas Kenari. Jurnal Agria 5 (1): 1-4.

Hardiman, T., Islami, T., Sebayang, H., T. 2014. Pengaruh Waktu Penyiangan Gulma pada Sistem Tanam Tumpangsari Kacang Tanah (Arachis hypogaea L.) dengan Ubi Kayu (Manihot esculenta Crantz.). Jurnal Produksi Tanaman 2 (2) : 111-120.

Hasanuddin, S. Hafsah, \& Sufiuddin. 2012. Pengaruh dosis herbisida campuran atrazina dan mesotriona terhadap pertumbuhan gulma pada tanaman jagung. Hal: 103-106.

D. Bakti, Rosmayati, L. Agustina, R. Handarini, S. Latifah, M. Tafsin, Razali, T. 
Sabrina, H. Hanum, E. Julianti, J. Ginting, T. Irmansyah, \& Fauzi (eds.). Prosiding Seminar Nasional dan Rapat Tahunan bidang Ilmu-ilmu Pertanian BKS-PTN Wilayah Barat Tahun 2002. Medan, 3-5 April 2012.

Hendrival, Zurrahmi Wirda, dan Abdul Azis. 2014. Periode Kritis Tanaman Kedelai Terhadap Persaingan Gulma. Universitas Malikussaleh.

Isna Ismawati. 2016. Bahan Kuliah Ilmu Teknik Perkebunan. Universitas Garut. Garut.Jatmiko., S.Y., Harsanti, S., Sarwoto., dan A.N. Ardiwinata. 2002. Apakah Herbisida Yang Digunakan Cukup Aman?.Prosiding Seminar Nasional Membangun Sistem Produksi Tanaman Pangan Berwawasan Lingkungan. Pusat Penelitian Dan Pengembangan Tanaman Pangan. Bogor.

Khan, H., K. B. Marwat, M. A. Khan, dan S. Hashim. 2014. Herbicidal Control of Parthenium Weed in Maize. Pakistan Journal of Botani. 46 (2) : 497 504.

Moenandir J. 1990. Fisiologi Herbisida. Jakarta: CV Rajawali.

Puspitasari, I., Nuhriawangsa, A. M. P. Dan Swastike W. 2013. Pengaruh Pemanfaatan Kunyit (Curcuma domestica Val.) terhadap kualitas mikrobia dan fisiko-kimia daging Sapi. Tropical Animal Husbandry J. 2(1) : 58-64.

Reade, P.H., \& A.H. Cobb. 2002. Herbicides: Modes of action and metabolism. $\mathrm{p}: 134-170$.

R.E.L. Naylor (ed.) Weed management handbook. 9th ed. Blackwell Science, Ltd., Oxford, UK.

Suprayono., dan A. Setyono. 1993. Padi. Penebar Swadaya. Jakarta.

Tim penulis PS. 1999. Sweet Corn. Baby Corn. Penebar Swadaya : Jakarta

Tharp, B.E., \& J.J. Kells. 2000. Effect of soil-applied herbicides on establishment of cover crop species. Weed Technol. 14:596-601.

Wichert, R.A., \& R.E. Talbert. 1992. Soybean [Glycine $\max ($ L.)] response to lactofen. Weed Sci. 41:23-37.

Zimdahl, R.L. 1980. Weed Crop Competition. A. Review. IPPC. Oregon. 